\title{
Quaternary Volcanoes of Indian Subcontinent: An Overview
}

Geological Survey of India, North Eastern Region, Shillong; Emails: tapan.pal1@gsi.gov.in, paltapan62@gmail.com

(Received : 15/12/2019; Revised accepted : 3/06/2019)

https://doi.org/10.18814/epiiugs/2020/020018

In Indian subcontinent one active volcano and another dormant volcano of Quaternary period are present in the Andaman Java subduction complex. The active Barren volcano throughout its history is erupting mainly tholeiitic basalt whereas the dormant Norcondam volcano is domal dacite and andesite volcano. In the Barren volcano wall, of $2 \mathrm{~km}$ wide caldera is made up of prehistoric ( $35 \mathrm{Ka}$ ) pyroclastics whereas the polygenetic tuff cone and valley fill are the products of historic (1787 yr) to recent activities of subaerial strombolian eruption and transient lava flows. The Barren volcanics dominated by plagioclase phyric basalt, in general, show phenocrysts of plagioclase $\left(\mathrm{An}_{96-48}\right)$, olivine $\left(\mathrm{Fo}_{86-67}\right)$ and clinopyroxene $\left(\mathrm{En}_{48-43}, \mathrm{Wo}_{46-42}\right)$. The geochemistry of the Barren volcanics show neither typical island arc nor $N$ MORB tholeiitic character. Tectonic model suggests that network of low-density, low viscosity conduits facilitated rapid transport of the basaltic melt with minimum crustal contamination for the Barren volcano. In the Narcondam volcano (1.8-3.5 Ma) dacitic lava occurs at the centraltop part whereas andesite lava and pyroclastics with calcalkaline characters occur at the periphery of the island. Pyroclastic deposit occurs in the form of basal avalanche, channeled basal avalanche, ash-cloud surge and base surge deposits. The mineralogy and texture suggests that the dacite-andesite lava is evolved from the mixing of rhyolite and basalt magma.

\section{Introduction}

In Andaman subduction complex, the oceanic part of the Indian plate is subducting obliquely at a rate of $\sim 60 \mathrm{~mm} / \mathrm{yr}$. below the Myanmar plate. Within Andaman Sea two Quaternary volcanoes one active Barren volcano and the other dormant Narcondam volcano represent sub-aerial volcano in the middle part of the inner volcanic arc chain (Fig.1a). This chain extends towards south to the Holocene Sumatran volcanic chain and towards north to the Quaternary volcanoes of the central Myanmar Lowlands (e.g., Luhr and Haldar,
2006). About sixty potentially active volcanoes including the Holocene giant super-volcano of Toba in Sumatra and the active volcanoes of Krakatau lie along this SE Asian volcanic rim (Evans and Crompton, 1946 cited in Shanker et al., 2001).

\section{Barren Volcano}

The Barren volcano covering 10 sq. km subaerial area has $2 \mathrm{~km}$ wide caldera with an opening towards west and $250 \mathrm{~m}$ high inner wall. The inner part of the caldera is occupied by an active, $>300 \mathrm{~m}$ high, polygenetic tuff cone (Luhr and Halder, 2006; Chandrasekharam, et al., 2009). Caldera wall is made up of prehistoric volcanics whereas historic and recent volcanic activities are confined within the caldera. This volcano has a base at a water depth of $\sim 2300 \mathrm{~m}$ with a diameter of $\sim 27 \mathrm{~km}$ and $355 \mathrm{~m}$ height above sea level and $3 \mathrm{~km}$ across in subaerial part.

The old eruptions of the Barren volcano have been well described, on the basis of work done by Geological Survey of India (GSI), written in the monograph by Shanker et al., 2001 and publication of Luhr and Haldar, 2006. The recent eruption (2005-2011) has been described by many (Bandopadhyay et al, 2006, Bandopadhyay, 2017, Pal et al., 2007a, 2010; Chandrasekharam, et al., 2009; Sheth et al., 2009, 2010, 2011, 2014). The petrography, mineral chemistry and geochemistry have been dealt by many workers (Luhr and Haldar, 2006, Pal et al., 2007a, 2010; Chandrashekharam, et al., 2009, Strecks et al., 2011). Age dating has been done by Strecks et al., 2011 and Ray et al., 2013, 2015. Recently a review on the Barren and Narcondam volcano has been done by Bandopadhyay, 2017 focusing mainly the eruption style of the Barren volcano upto 2006 eruption with a brief description on geochemistry and petrography. In the present text additionally field observation upto 2011 eruption, mineral chemistry, petrology, geochemistry and petrogenesis and age of the Barren volcano have been dealt for tectonic evolution of the volcano. For the Narcondam volcano the different pyroclastic deposits, lava have been dealt together for its genetic model.

\section{Eruption history of Barren Volcano}

The Barren Island witnessed volcanic activity from pre-historic time. The historical records of volcanic activity, however, date back to 1787. In general three cycles of eruption have been reported: (a) first cycle during pre-1787 period (pre-historic); (b) second cycle during 1787-1832 and (c) third cycle during 1991-2011. Third cycle shows three stages with the first stage during 1991, the second stage 


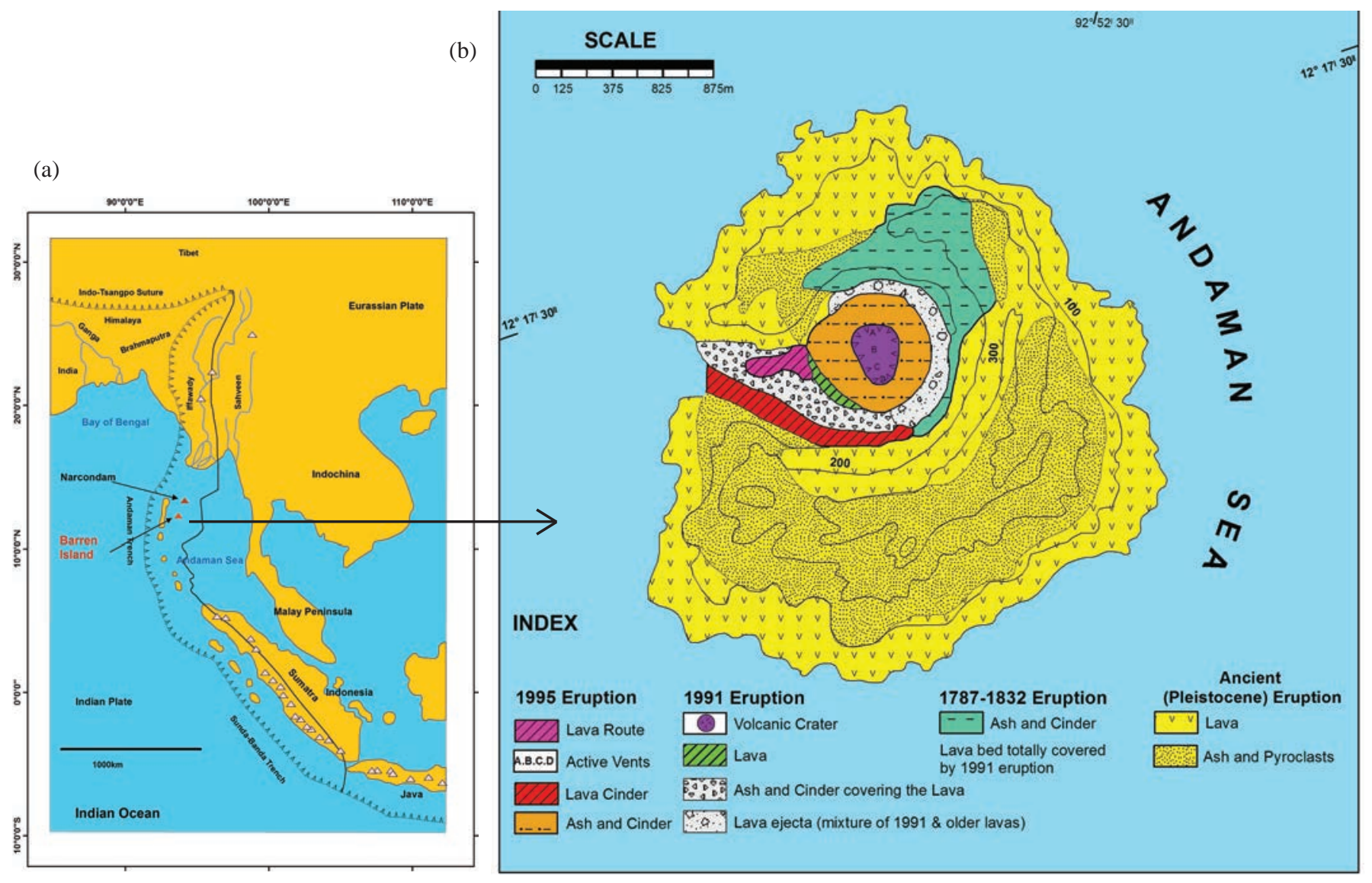

Figure 1.(a) Location of Barren and Narcondam volcanoes in the backdrop of Andaman subduction Complex. Triangle symbols volcanoes of Indonesia-Andaman volcanic arc (based on Luhr and Halder 2006 and references therein), (b) Geological map of the Barren Island volcano showing eruption products prior to 2005-2011eruption (modified after Shanker et al 2001)

during 1994-95 and the third stage during 2005-11. Besides the lava flow and pyroclastics, few dykes have also been reported in southern part of caldera (Alam et al., 2004). The products of different eruptions are depicted in the geological map produced by Geological Survey of India before 2005 eruption (Fig.1b). The recent products have covered the products of 1991, 1994-95 explosions, which were exposed earlier near the mouth of the valley and southern side of the valley (Fig.2).

\section{Pre-1787 eruption}

The interstratified beds of the pyroclastics and lava flows of basaltic to andesitic composition are now preserved as the caldera wall. In the western part of the caldera wall the pyroclastic deposits show the sequence of agglomerate, massive beds, graded bedding, current bedding, and beds with penecontemporaneous structures (Luhr and Halder, 2006; Shanker et al., 2001). Sheth et al., 2009 have described different features of pyroclastics in terms of lahar, pyroclastic fall and surge deposits.

\section{Historic (1787-1832) eruption}

This historical eruption was subaerial Strombolian type. First historically recorded eruptions in 1787 were observed by passenger ships crossing the Andaman Sea. From the crater and vents initially a huge amount of blocks and scoria (cinder and ash) of basaltic composition had been ejected and deposited as lava debris (Blair, 1789 cited in Shanker et al., 2001.) Shanker et al., 2001 described some ropy lava from the basaltic lava flow of historic period. But Sheth et al., 2011 has reinterpreted the same as toothpaste "aa" lava of 1991 or 1994-95 eruption. But its occurrence in the midst of historic lava flows may indicate pre-1991 age (Bandopadhyay, 2017).

\section{1 eruption}

The third cycle of eruption changed from Strombolian type to violent explosive (Shanker et al., 2001). During this stage huge mass of ash, lava debris, cinder of basaltic andesite covered an area of $\sim 0.26 \mathrm{~km}^{2}$ overlapping large parts of the earlier eruptive products. This eruption resulted in a big crater (400 m wide and 200m deep), cinder cones and spatter cones. The 1991 lava flows were basaltic andesites but scoria sample was basaltic in composition( Shanker et al 2001).

\section{4-95 eruption}

The second phase of third cycle started in 1994 and continued up to 1995 . The 1994-1995 eruption was mainly Strombolian ejecting gas, ash and steam, and covered an area of $\sim 0.23 \mathrm{~km}^{2}$. Overall the eruption was olivine basalt. Blocky lava travelled about $1.5 \mathrm{~km}$ to reach the sea producing profuse steaming at the ocean entry (Shanker et al., 2001). 


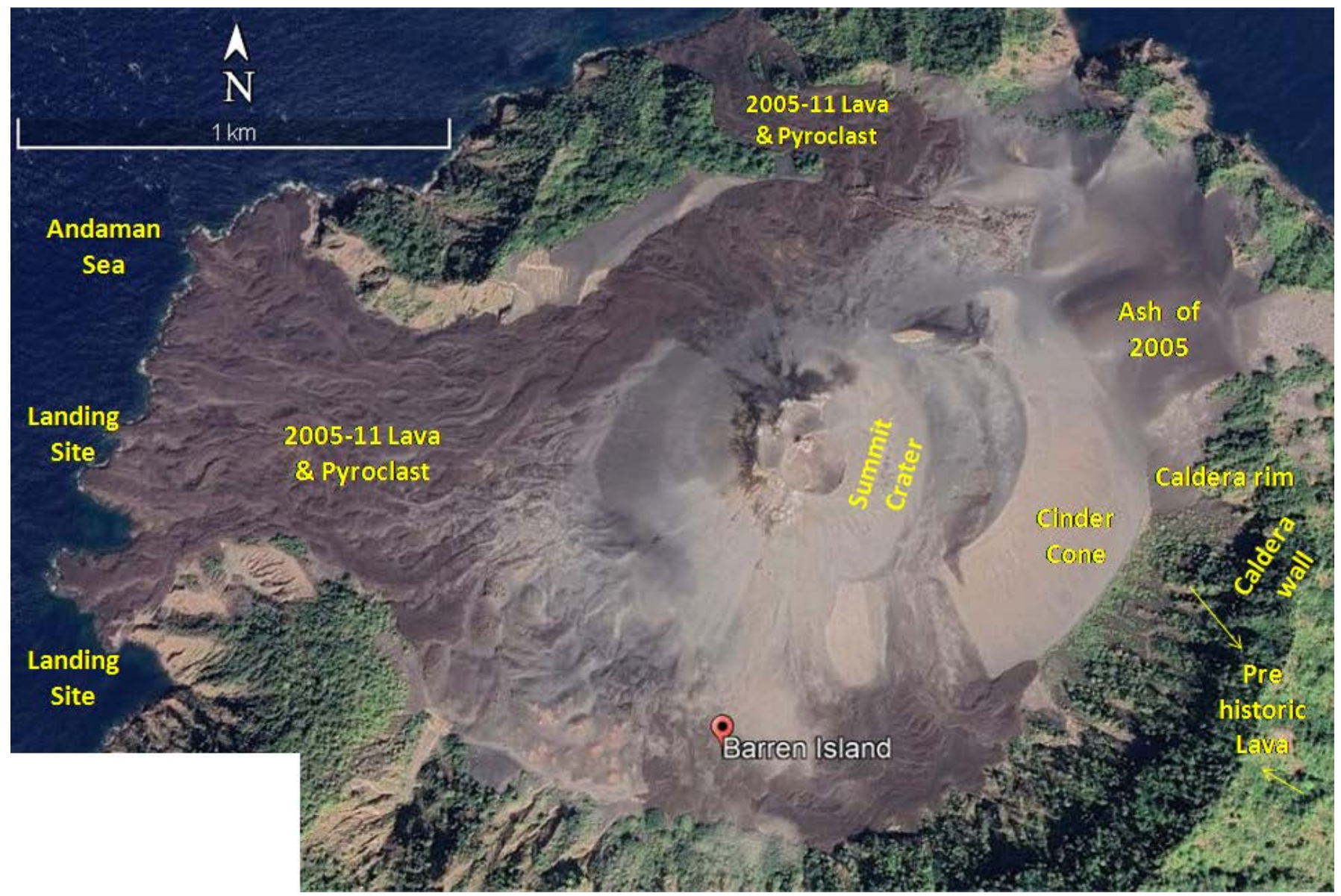

Figure 2. Geomorphology of the Barren Island based on Google Earth image. (imagery date 16 January 2017). Some of the volcanological features are also marked in the image

\section{5-11 eruption}

2005-2006 observation: A subaerial, mild Strombolian eruption of the Barren volcano, started on 28 $8^{\text {th }}$ May, 2005 (Fig.3) (Bandopadhyay

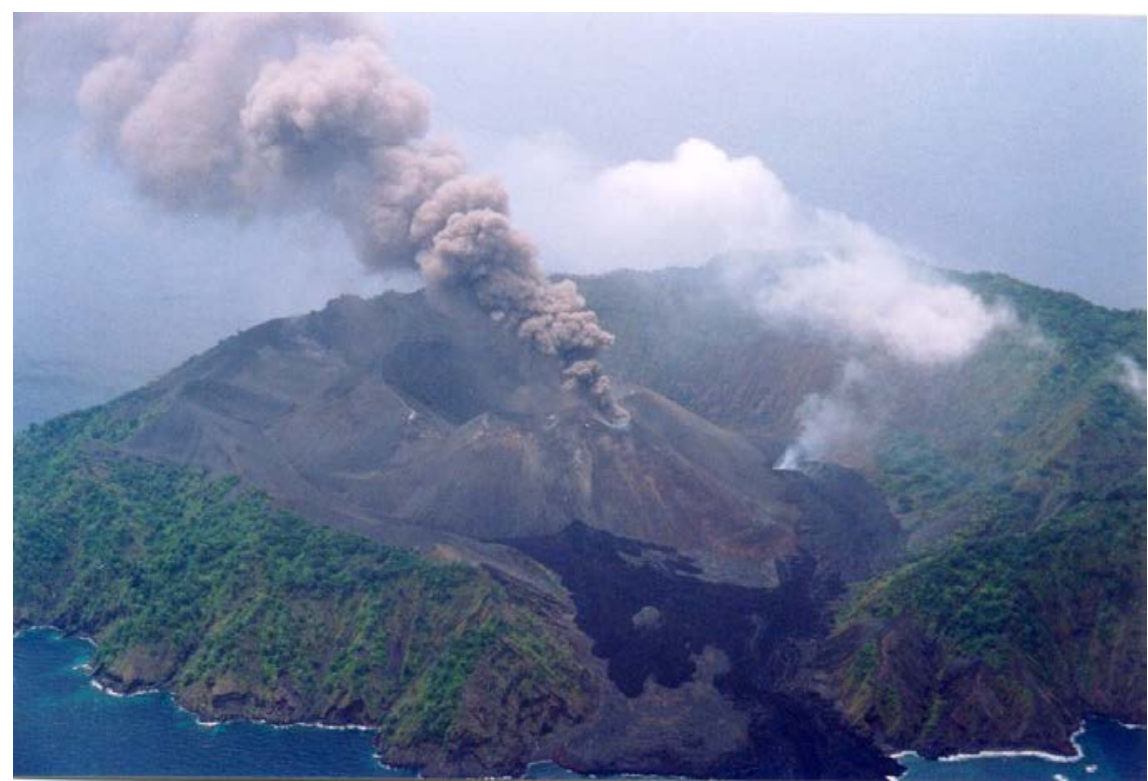

Figure 3. Barren volcano in the beginning of 2005 eruption (photo courtsey Indian Coast Guard) et al., 2006, Pal et al., 2007a, 2010). The style of Strombolian activity was followed by intermediate scale fire fountain and Strombolian explosions (e.g.,. Bandopadhyay et al., 2006). The coarser tephra was represented by lapilli, cinder, spatter and blocks. During March 2006 volcanic activity diminished significantly. By that time the main approach valley to the island was closed by a thick pile of assorted fragmentary ejecta of 2006 eruption. The pile of assorted pyroclasts formed very uneven topography ranging from heap to ridge to depression at places.

2008 observation: During that time volcano again was Strombolian in nature. Chandrashekaram et al., 2009 observed the formation of a new cinder cone to the south of the existing cone.

2009-2011 observation: The Strombolian type eruption continued in the southern flank of the main cinder cone. During 2009-11 eruption along with pyroclastics transient " $a a$ " lava flowed over the northern wall of the landing site (Fig4). The main approach valley to the centre of the island situated at the western part was totally covered by a thick pile of assorted pyroclasts and " $a a^{\text {" }}$ 


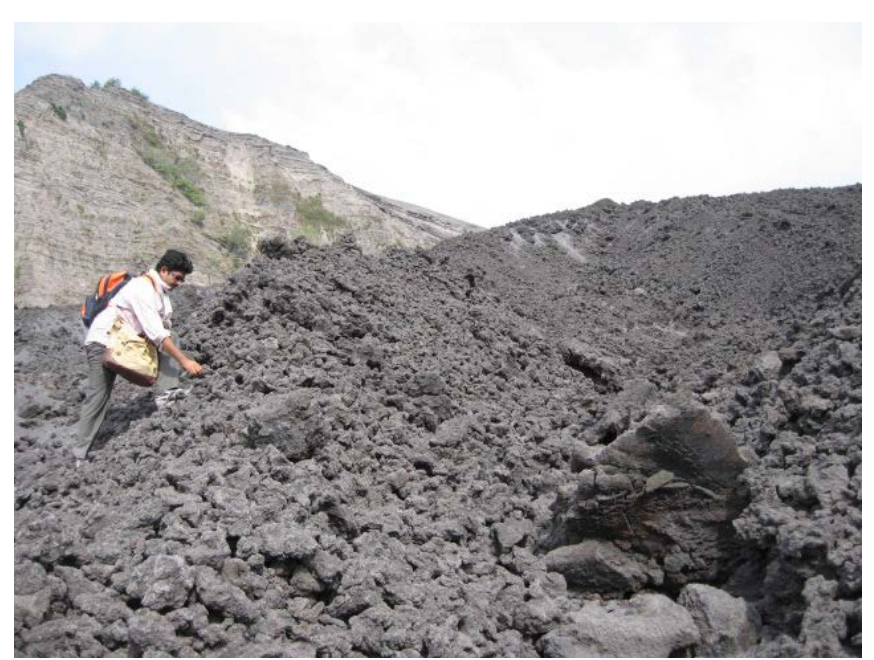

Figure 4. The assorted pyroclasts and toothpaste 'aa" lava of the 2005-2011 eruption.

lava of recent eruptions (Fig.5). Besides the main flow of pyroclasts and lava in the western part of the valley, a considerable amount of lava and pyroclasts had filled up the valley in the NNW part of the island overflowing the caldera wall and reached the sea-shore (Fig.6).

\section{Nature of Lava and pyroclasts}

The lava flows of the Barren Island from pre-historic to present time are "aa" type. The lava flows of the recent eruption are volumetrically less compared to the volume of the pyroclastic flow. Shanker et al., 2001, described some lava as "pahoehoe with ropy structure", but these lavas have been ascribed as toothpaste " $a a$ " flow by Sheth et al., 2009.

The pyroclasts occur as assorted mixture of blocks, cinders, spatter, lapilli and ash. Pyroclastic deposit in the form of lava blocks, spatters and cinders are set in ash matrix (Fig.7). At some places pyroclasts occur in the form of semi consolidated beds with a coarsening upward sequence and the mass forms ridge and furrow topography.

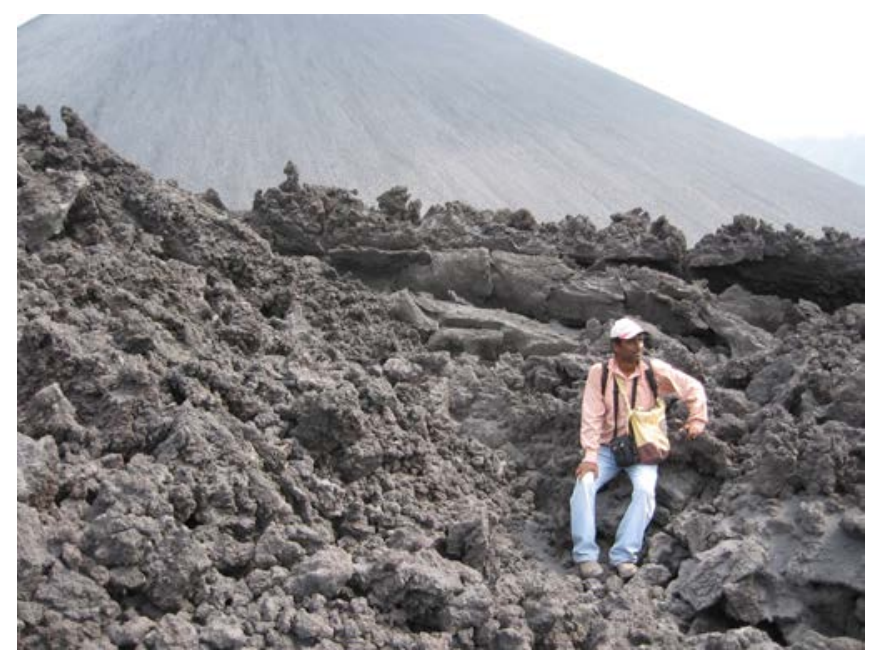

Figure 5. "aa" lava with a massive to jointed base and jagged, Spinose, clinkery top of 2005-2011 eruption.

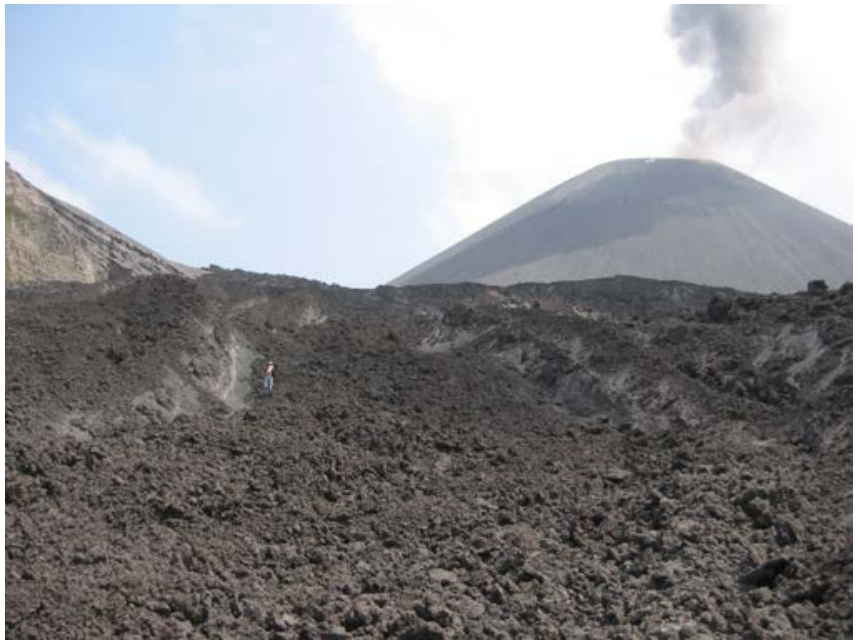

Figure 6. Pyroclasts filling the northwestern part of the crater of recent eruption (2005-11eruption), observation in 2011

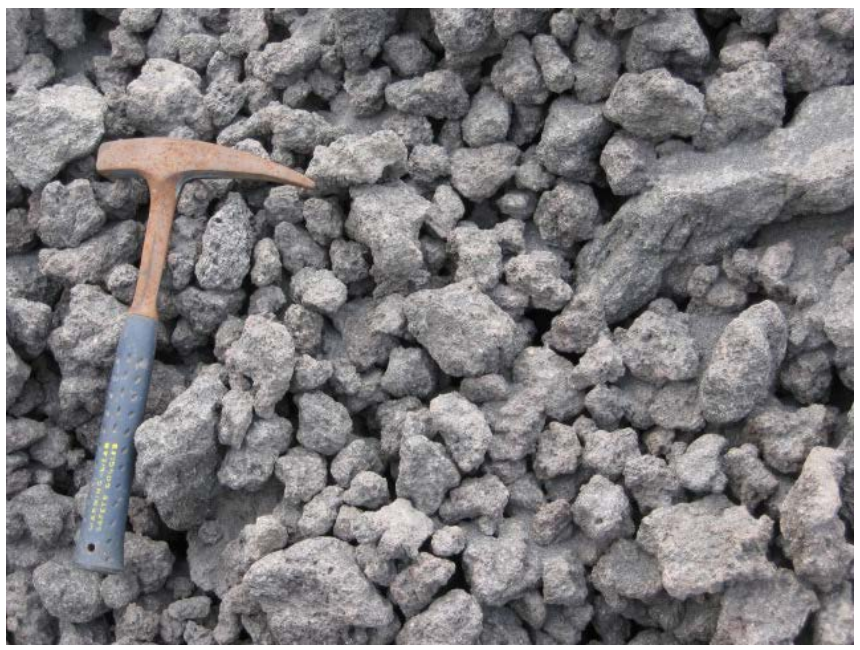

Figure 7. Cinders of basalt of 2005-11 eruption of Barren Volcano observation in January, 2011

\section{Petrography}

Barren volcanics, of all the eruptions, are plagioclase phyric basalt and show phenocrysts of plagioclase, olivine and clinopyroxene set in a glassy to microcrystalline matrix of clinopyroxene and plagioclase microlites (Luhr and Halder, 2006, Chandrasekharam et al., 2009, Pal et al., 2010). Pre-historic rock compared to other eruptions is coarsely crystalline and contain abundant plagioclase phenocrysts (Luhr and Halder, 2006). The pyroclasts of recent eruption (200511) are highly vesiculated vitrophyric basaltic rock where phenocrystic grains are mainly of plagioclase (20 to 35 vol\%) and minor olivine (1-4 vol\%), and clinopyroxene (0.5.5-2.5vol\%). Olivine phenocrysts are sometimes well resorbed (Fig.8). Xenocrystic olivine and plagioclase grains from trocolite have also been reported (Luhr and Haldar, 2006, Sheth et al., 2009).

\section{Mineral Compositions}

\section{Olivine}

Olivine grains of Pre-1787 lava has $\mathrm{Fo}_{75-64}$ composition, 1787- 


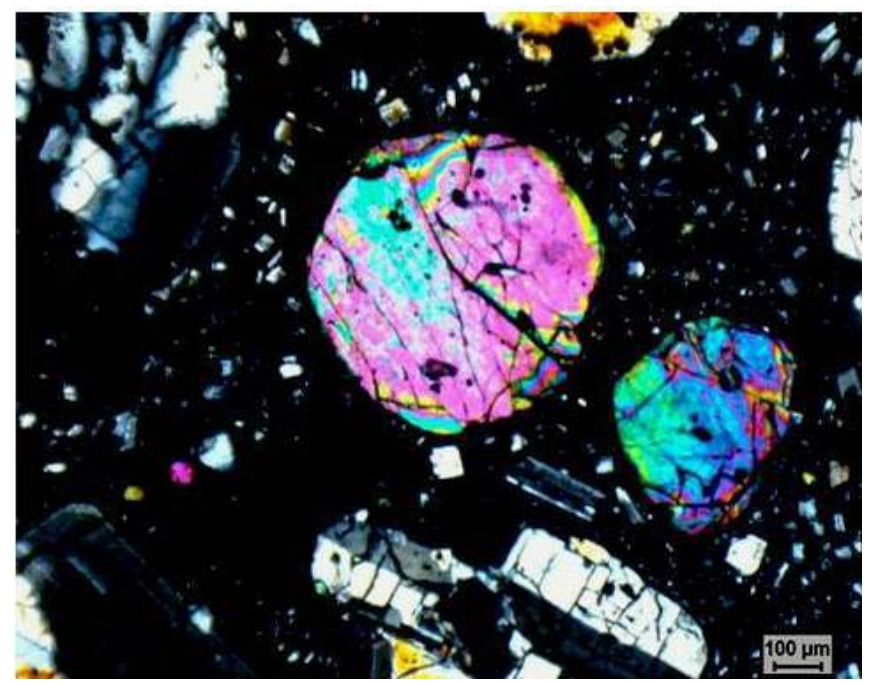

Figure 8. Porphyritic basalt of 2005-2011 eruption of the Barren Volcano showing resorbed olivine phenocrysts.

1832 lava show strong variation from core $\left(\mathrm{Fo}_{86}\right)$ to rim $\left(\mathrm{Fo}_{67}\right)$ and 1991 eruption show a uniform composition $\left(\mathrm{Fo}_{82-86}\right)$ (Pal et al., 2010). Luhr and Halder, (2006) reported forsteritic core $\left(\mathrm{Fo}_{74-79}\right)$ for both1991 and 1994-1995 lavas. The olivine grains of 2005 lava shows a compositional variation from core $\left(\mathrm{Fo}_{81-85}\right)$ to $\operatorname{rim}\left(\mathrm{Fo}_{73-75}\right)$ but the 2006-2011 lava shows uniform composition $\left(\mathrm{Fo}_{75-78}\right)$. The olivine composition therefore shows a very similar crystallisation condition for Pre-1787, 1991 and 2006-11 eruptions forming one group and 1787-1832, 2005 eruptions for another group.

\section{Feldspar}

The Pre-1787 eruption phenocrystic feldspar show zoning with $\mathrm{An}_{90-96}$ core to $\mathrm{An}_{48}$ rim (Luhr and Halder, 2006). Feldspar phenocrysts of the 1787-1832 lava has $\mathrm{An}_{93}$ to $\mathrm{An}_{85}$ composition, and 1991 lava has $\mathrm{An}_{57}$ to $\mathrm{An}_{78}$ composition. The phenocrysts of 1994-95 lava also show $\mathrm{An}_{89}$ core to $\mathrm{An}_{87}$ rim composition. Feldspar phenocrysts of 2005-11 eruption show compositional range from $\mathrm{An}_{63}$ to $\mathrm{An}_{91}-\mathrm{An}_{81}$ to $\mathrm{An}_{91}-\mathrm{An}_{94}$. The feldspar of 1787-1832, 1994-95 and 2005 lavas therefore shows mainly anorthitic composition whereas that of pre-1787, 1991 and 2006-11 lavas shows bytownite field suggesting evolved nature of Pre-1787, 1991 and 2006-11 lava (Pal et al., 2010).

\section{Pyroxene}

The Pre-1787 eruption shows enstatite and augite composition. The clinopyroxene grains in 1787-1832 lava are augite but the grains of 1991 eruptions are diopsidic to augitic without any compositional zoning (Pal et al., 2010, Luhr and Halder, 2006). In the 1994-95 eruption phenocrysts are augite, similar to 1787-1832. In 2006 lava both phenocryst and microphenocrysts are augite with a variation from core $\left(\mathrm{En}_{48}, \mathrm{Wo}_{46}\right)$ to rim $\left(\mathrm{En}_{43}, \mathrm{Wo}_{42}\right)$ (Pal et al., 2010).

\section{Glass}

Glasses are trachy andesite for pre-1787, basalt to basaltic andesite for 1787-1832, trachy andesite to dacite for 1994-95 lava and basaltic for in 1991 and 1994-95 eruptions (Luhr and Halder, 2006). The
2005 to 2006 eruption shows wide range with picro-basalt to basalt to basaltic andesite-andesite field (Pal et al., 2010).

\section{Whole rock geochemistry}

Major oxides of Barren volcanics of different eruptions reported by many (Shanker et al., 2001, Pal et al., 2010, Sheth et al., 2009; Chandrashekharam et al., 2009) show restricted composition ranging from basalt to basaltic andesite (Fig. 9). Some layers of Pre-historic

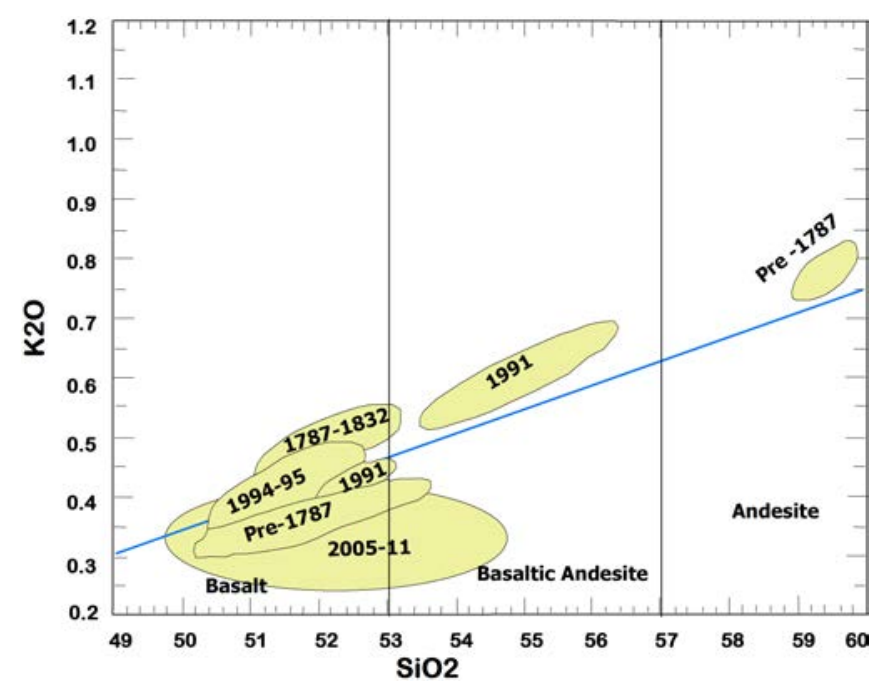

Figure 9. The $\mathrm{K}_{2} \mathrm{O}$ vs $\mathrm{SiO}_{2}$ plot shows basalt to basaltic andesite character of the Barren volcanic. Data source Luhr and Haldar (2006), Chandrashekharam et al 2009, Pal et al 2010, Sheth et al 2011.

lava show a primitive nature of basalts with $8 \mathrm{wt} \% \mathrm{MgO}$ and $~ 300 \mathrm{ppm}$ $\mathrm{Cr}$ and 130 ppm Ni (Luhr and Haldar, 2006). In trace elements pattern pre-1787 to 1995 lava are enriched in LILE with island arc tholeiitic character, typical of subduction zone magmas (Halder et al., 1992; Luhr and Halder, 2006). The REE values reported by Chandrashekharam et al., 2009 show that pre-1787 rocks have slightly depleted LREE and a flat HREE and the subsequent eruption had identical patterns with LREE enriched pattern. For the recent eruption a decreasing trend of $\mathrm{MgO}, \mathrm{CaO}, \mathrm{Al}_{2} \mathrm{O}_{3}, \mathrm{Fe}_{2} \mathrm{O}_{3}$ and $\mathrm{TiO}_{2}$ and alkalies against $\mathrm{SiO}_{2}$ has been observed by Pal et al., 2010. The distribution of trace elements against $\mathrm{SiO}_{2} \%$ also show the restricted and clustering nature of 2005-lava whereas 2006 -lava had an evolved path (Fig.10).

The distribution pattern of REE of the samples of 2009-2011 show moderately to highly enriched REE pattern whereas pre-1787 lava has flat REE pattern (Fig.11). Barren tholeiites with Th/Nb (1.52.5) (Ba/Th 60 , U/La 0.04, and (La/ Sm) N = 0.9-1.3) (U/Th of $\sim 0.17$; $\mathrm{Nb} / \mathrm{Zr}$ of $\sim 0.01$ ) have neither typical MORB nor Island arc character (Strecks et al., 2011).

\section{Sr and Nd isotopes}

Sr isotopic ratios vary from 0.70380 to 0.70403 with wide variability in the pre-historic products whereas the other eruptions show values near 0.704 or less (Luhr \& Haldar, 2006, Chandrashekharam et al., 2009, Strecks et al., 2011). Nd isotope ratios with a range $0.512860-0.513005$ display an overall negative correlation with ${ }^{87} \mathrm{Sr} /{ }^{86} \mathrm{Sr}$. The scattered positive correlation by ${ }^{87} \mathrm{Sr} /$ 


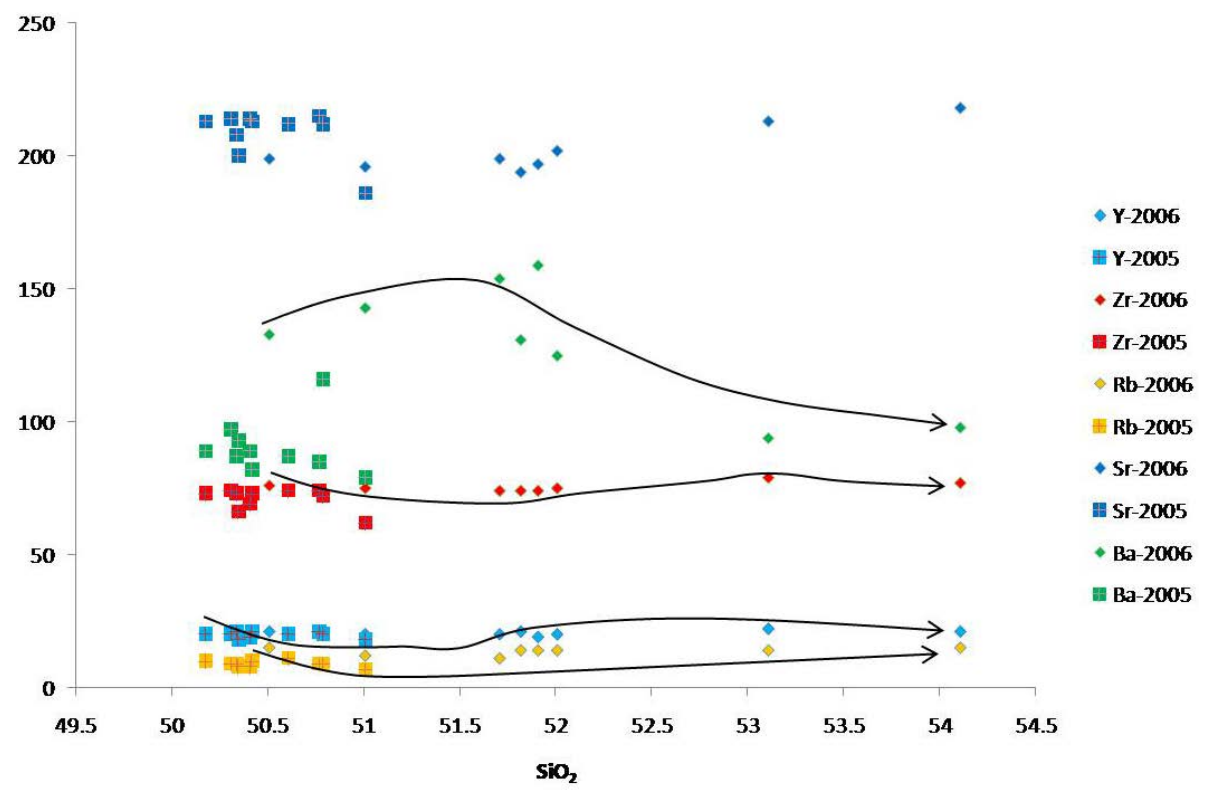

Figure 10. The bivariant plot of trace element against $\mathrm{SiO}_{2} \%$ showing clustering for 2005 lava and evolved magma nature for 2006 lava (data after Pal et al., 2010).

${ }^{86} \mathrm{Sr}$ and $\mathrm{Th} / \mathrm{Ta}$ ratios and the negative correlation between $\mathrm{Nd}$ isotope ratios and Th/Ce ratios of Barren lava suggest slab sediment contamination to the mantle source (Chandrashekharam et al., 2009).

\section{Age Dating}

The oldest lava flows and ash deposits of the Barren Island are too young to be suitably dated by long lived radio isotopic methods. Haldar et al., 1992; Shanker et al., 2001 suggested that the Barren volcano first erupted in late Pleistocene time. However ${ }^{40} \mathrm{Ar} /{ }^{39} \mathrm{Ar}$ values for Pre-historic lava yields $33 \pm 70$ and35 \pm 88 Ka age, (Strecks et al., 2011). Awasthi et al., 2010 dated different ash layers interlayered with marine sediments from the sediment core near Barren volcano as $\sim 70,69,61,24,19,15$ and 10 ka. Ray et al., 2013, 2015 dated

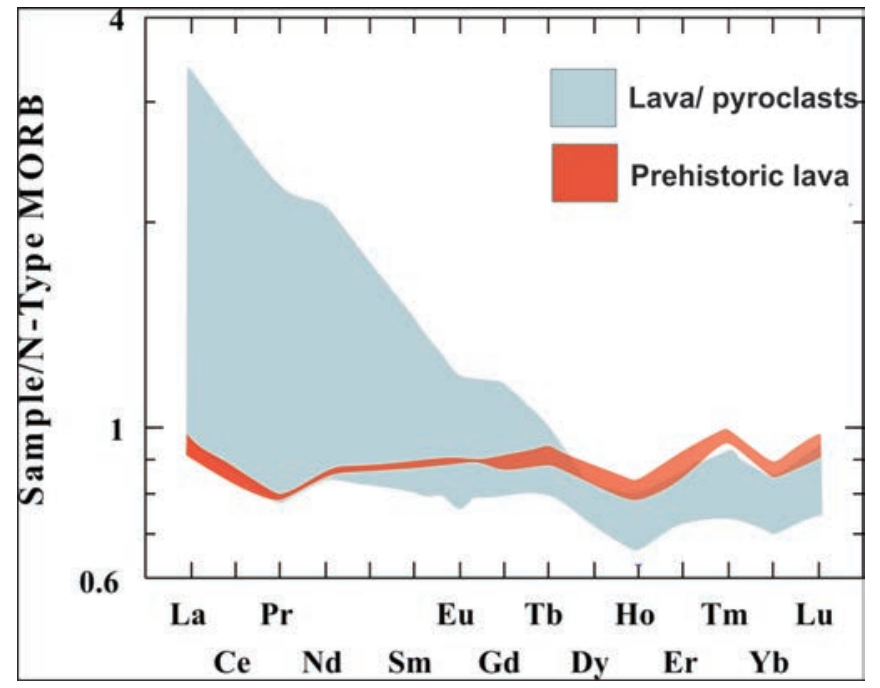

Figure 11.The REE distribution of 2009-2011 samples showing LREE enrched pattern compared to Pre-historic lava (data after Bhattacharya et al., 2012). ash layers from the core by ${ }^{40} \mathrm{Ar} /{ }^{39} \mathrm{Ar}$ method which yields 1.5 -1.8 Ma, suggesting that old magmatic rocks were present in the plumbing system of the volcano.

\section{Source character and anhydrous nature of magma}

Throughout the evolutionary history of the Barren volcano having basaltic magma suggests homogenous mantle source (Pal et al., 2010). The enriched LILE pattern reflects that the enrichment of the mantle wedge in the subduction zone setting was either by fluids derived from subducting slab or by the subducted sediments (Luhr and Halder, 2006, Pal et al., 2010). Presence of abundant plagioclase phenocrysts supports the anhydrous to negligible water content of the magma. High Zr content (48ppm - 100ppm) of the Barren lava also corroborates its anhydrous nature (e.g., Pal et al., 2010). Isotopic ratios ${ }^{143} \mathrm{Nd} /{ }^{144} \mathrm{Nd}(\sim 0.51270),{ }^{87} \mathrm{Sr} /$ ${ }^{86} \mathrm{Sr}$ ( 0.7039-0.7041) and ${ }^{206} \mathrm{~Pb} /{ }^{204} \mathrm{~Pb}$ ( 18.565-18.617,) and ratios of incompatible trace elements however suggest that basaltic rocks were influenced by additional evolutionary processes and/or caused by heterogeneous magma source (Strecks et al., 2011).

\section{Magma genesis model}

As the Barren basalt is nearly anhydrous, water fluxing from subducting slab had a negligible effect in melting of mantle peridotite. During subduction, a rigid oceanic slab induced convection and upwelling in the overlying mantle wedge and produced hot, fingerlike regions and initially a hydrated diapir was formed above the cool subducting slab which gradually converted to hot and dry diapir ( Fig.12) (e.g., Tamurai, 1994, Pal et al., 2010).

During its ascent into the overlying hot mantle wedge, hot and dry rind of the diapir yielded anhydrous basalt whereas cooler and wet core of the diapir produced basaltic andesite. Pal et al., 2010

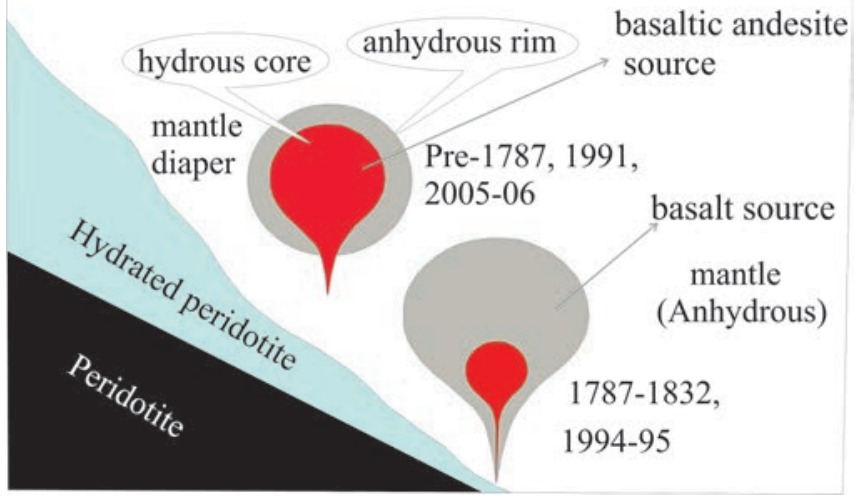

Figure 12. Mantle diapiric model showing the magmatic evolution of the Barren Volcano (after Pal et al., 2010). Anhydrous basalt is derived from the hot and dry rind and basaltic andesite formed from the cooler and wet core of the diapir. 
suggested that a network of low-density, low viscosity conduits produced by mantle flow facilitated rapid transport of the basaltic melt with minimum crustal contamination for the Barren volcano.

\section{Narcondam Volcano}

Narcondam island, a domal and dormant volcano, is located 135 $\mathrm{km} \mathrm{NE}$ of the main Andaman and Nicobar group of islands with an exposed area of $7 \mathrm{~km}^{2}$ and a maximum height of $710 \mathrm{~m}$. A limited study was done initially by Mallet, 1885, Hobday and Mallet, 1885 and Ball, 1983. They reported the presence of andesite lava without any crater activity. Halder, 2007, Pal et al., 2007b and Strecks et al., 2011 described petrologic, geochemical and geochronological attributes. Pal et al., 2007b invoked the mixing of magmas mechanism and Pal and Bhattacharya, 2011 have reported different forms of pyroclastic deposit and described a genetic model.

\section{Field features}

Top of the volcano is circular in shape with an around $20 \mathrm{~m}$ diameter and is covered by jointed blocks of dacite. No volcanic crater is found in the blocky exposures of the summit (Mallet, 1885, Pal and Bhattacharya, 2011). The plagioclase phyric andesite lava occurs dominantly at the rim and slope of the island and plagioclaseamphibole-biotite phyric dacite occupy the central part of the island. Different forms of the lava and pyroclastic deposits are reported from the north western and north eastern coastal segments by Pal and Bhattacharya, 2011.

\section{Lava}

Dacitic lava occurs largely at the central-top part of the island whereas andesitic to amphibole-andesite lava are found at the basal part and north eastern edge of the island. In the wall autobrecciated lava is also common (Fig.13). The phenocrysts of prismatic and tabular

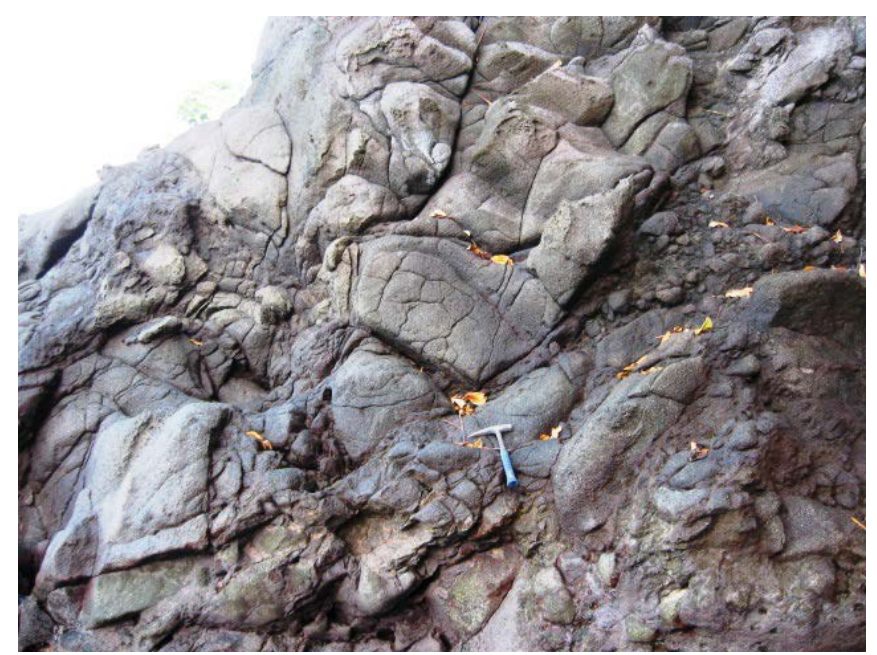

Figure 13. Auto-brecciated lava of Narcondam Volcano.

grains of amphibole, rectangular biotite and plagioclase laths within fine grained groundmass are common in light grey porphyritic dacitic lava whereas plagioclase phyric reddish brown to dark grey andesite lava shows dominance of plagioclase over pyroxene, amphibole and olivine.

\section{Pyroclastic deposit}

Pal and Bhattacharya, 2011 have recognized four types of pyroclastic deposits as discussed in the following section.

\section{Basal avalanche deposit}

Lower part of this unit shows grain supported beds and the upper part is dominated by matrix supported pyroclastic deposit. The lower part representing massive to very weakly graded beds contain assorted mixtures of angular to sub angular non vesiculated to poorly vesiculated blocks of andesite. Towards up section grain-supported massive beds change into reverse graded matrix supported beds. The normally graded channel fill deposit is overlain by repetitive beds of inversely graded lapilli breccia to tuff breccia (Fig.14). The matrix

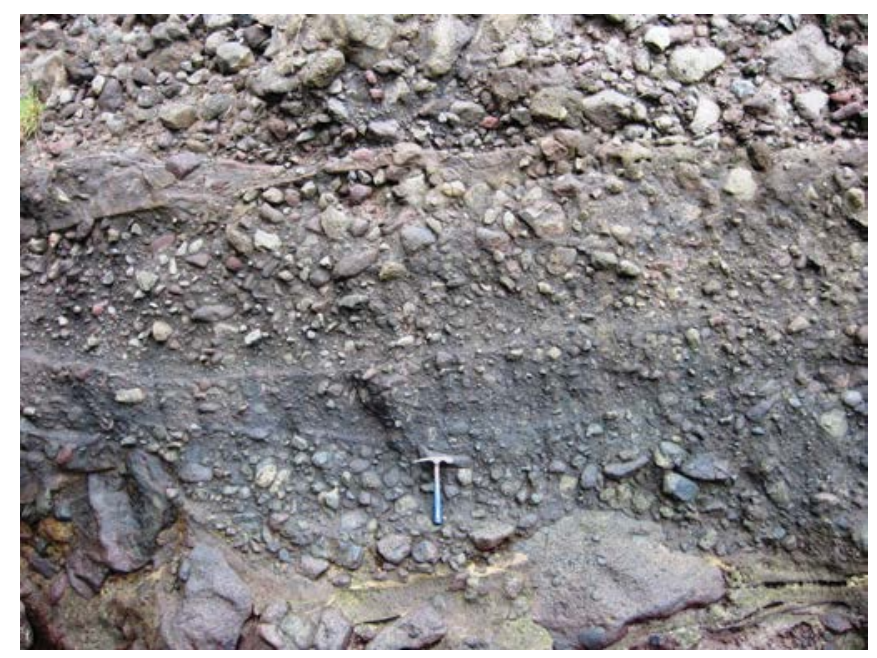

Figure 14. Pyroclastics of Narcondam Volcano showing channel fill by large blocks and spatter clast, followed upwards by of reversely graded lapilli breccia to tuff breccia

supported, reverse graded beds with the channel base containing agglutinated clasts suggest hot basal avalanche deposit rather than those of cold lahar. The thermal contraction of large blocks produced from dome collapse contributed to the extensive shattering, and fines produced by shattering increased the mobility of the debris to travel as a basal avalanche. Closely spaced dome collapse events led to overlapping of individual flows to produce such indistinct stratification.

\section{Ash-cloud surge deposit}

The impersistent unit of thinly bedded lapilli tuffs is sandwiched in between two different beds of basal avalanche deposit. This tuff sequence showing normal grading and parallel laminations, containing crystal fragments, lithic fragments and blocky glass shards and confinement within basal avalanche are characteristics of ash - cloud surge deposits.

\section{Base surge deposit}

In this stratified unit thin parallel beds of tuff contain numerous andesitic blocks, bombs and lapilli. The ballistic bombs produced at 
the explosive phase and laminated units formed during an extended period of explosive eruption .

\section{Petrography}

The Narcondam volcanics are represented by (a) porphyritic dacite, (b) amphibole-andesite and (c) andesite (Pal et al., 2007b). The sodic plagioclases, occurring as unreacted grains in dacite and as cores of the reacted grains in andesite, as well as the presence of rhyolitic glass as inclusions, record rhyolitic liquid as one of the magma source. On the other hand preponderances of phenocrysts of basaltic origin $\left(\mathrm{Fo}_{87-89}\right.$ olivine and $\mathrm{En}_{42-47}, \mathrm{Wo}_{37-47}$ pyroxene) as well as basaltic glass suggest basaltic magma as another source. In reacting grains, the fresh andesine $\left(\mathrm{An}_{46-49}\right)$ core was derived from acid magma and the reacting zones showing labradorite $\left(\mathrm{An}_{60-65}\right)$ composition were developed by the reaction of andesine crystals with hot basic magma (Fig.15). Amphibole grains were also replaced by pyroxene grains during heating (Fig.16). The presence of phenocrysts of both felsic

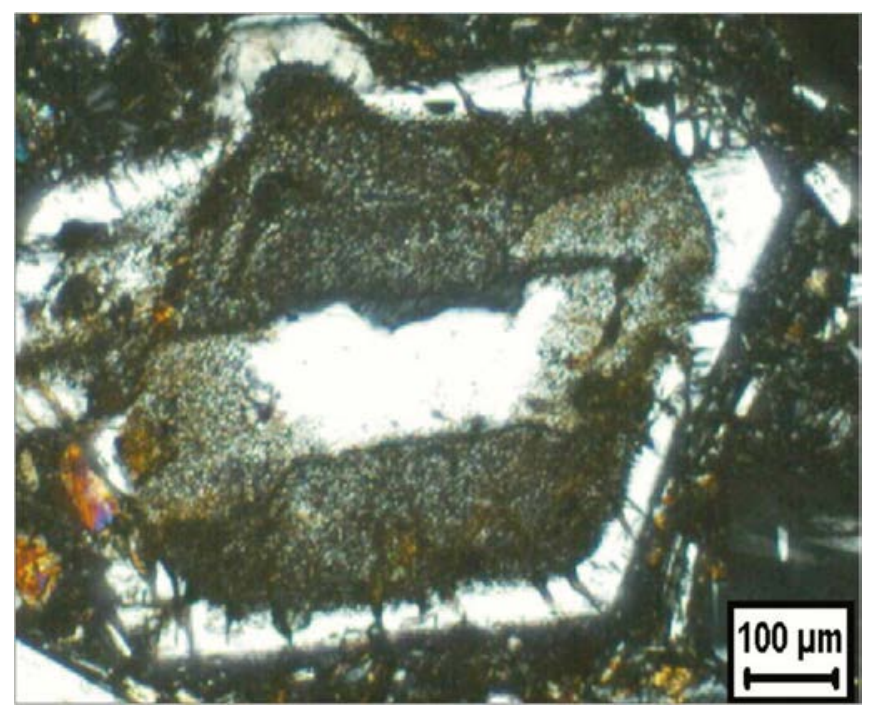

Figure 15. Photomicrograph showing magma mixing features where fresh grains of andesine surrounded by the dusty zone which in turn fringed by a thin clear rim of bytownite of Narcondam volcanics

and basic magmas and glasses indicate that dacite, amphibole-andesite, and andesite are the products of magma mixing (Pal et al., 2007b).

\section{Bulk Chemistry}

The major oxides and the $\mathrm{FeO}$ (total)/ $\mathrm{MgO}$ vs $\mathrm{SiO}_{2}$ relation shows the calc alkaline nature of both lava and pyroclasts. Although both lava and pyroclasts have elevated $\mathrm{Al}_{2} \mathrm{O}_{3}$ (16-19wt. \%.), lava shows strong decreasing trend compared to pyroclasts as their $\mathrm{SiO}_{2}$ content increases. The trace elements pattern shows enriched LILE relative to HFSE as well as a strong positive anomaly in respect of N-MORB (Fig.17). Andesitic/dacitic lavas are medium K, arc lavas similar to those erupted along the arc in Sumatra and Java (Strecks et al., 2011). Narcondam lavas are distinctly more radiogenic than Barren Island lavas. Narcondam lavas have ${ }^{87} \mathrm{Sr} /{ }^{86} \mathrm{Sr}$ ratios greater than 0.7051 and $\mathrm{Pb}$ isotope ratios also vary significantly with ${ }^{206} \mathrm{~Pb} /{ }^{204} \mathrm{~Pb}$ ratios of greater than 18.56 (Strecks et al., 2011).

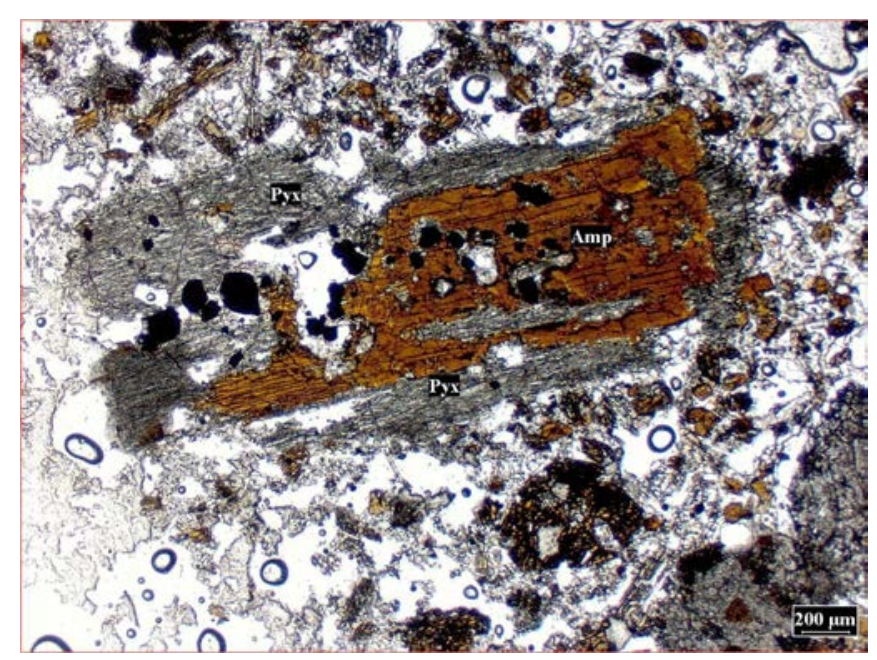

Figure 16. Photomicrograph showing magma mixing features where amphibole grains are partly replaced by pyroxene grains of Narcondam volcanics

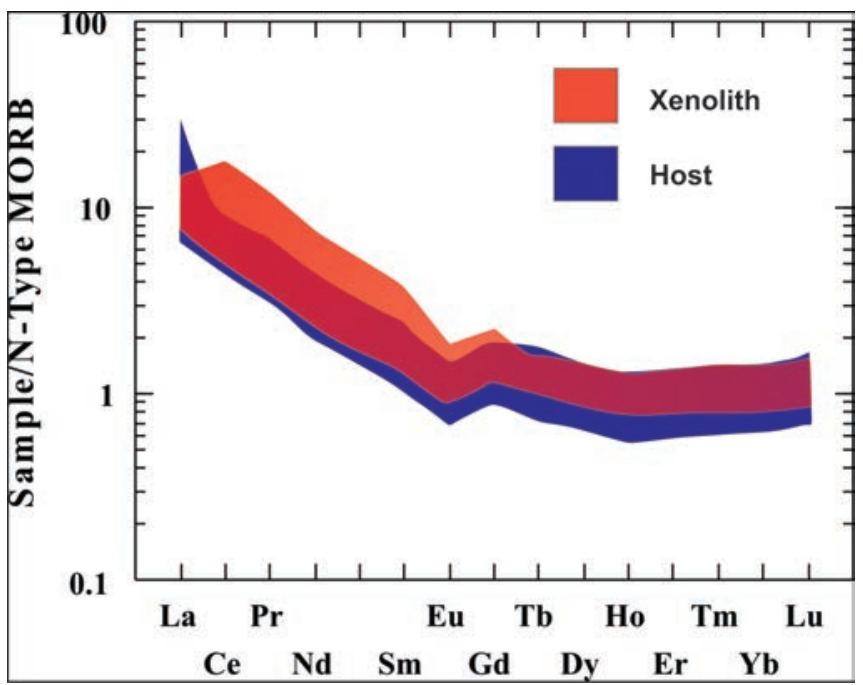

Figure 17. The distribution of REE of the Narcondam lava and pyroclasts showing enriched LREE pattern (data after Mukhopadhyay et al., 2009).

\section{Evolutionary model}

The andesitic viscous magma initially filled the vent. Then the highly explosive vulcanian eruption had blown off the top of andesitic dome and large sized pyroclasts were thrown out. Then the debris moved as high velocity flow along the steep flanks of the dome as basal avalanche (Fig.18a). Subsequently magma changed to highly viscous dacitic composition and a dacitic dome extruded the edifice and produced the present day shape of the volcano (Fig.18b). Thus the volcano represents the diverse episodes of volcanic activity including effusive dome growth, explosive eruption, dome collapse, hot avalanches and ash-cloud surge (Pal and Bhattacharya, 2011).

\section{Age of Narcondam volcano}

${ }^{40} \mathrm{Ar} /{ }^{39} \mathrm{Ar}$ step-heating analyses of plagioclase xenocrysts from Narcondam yielded age ranges of between $1.8+0.3 \mathrm{Ma}(2 \mathrm{~s})$ and 

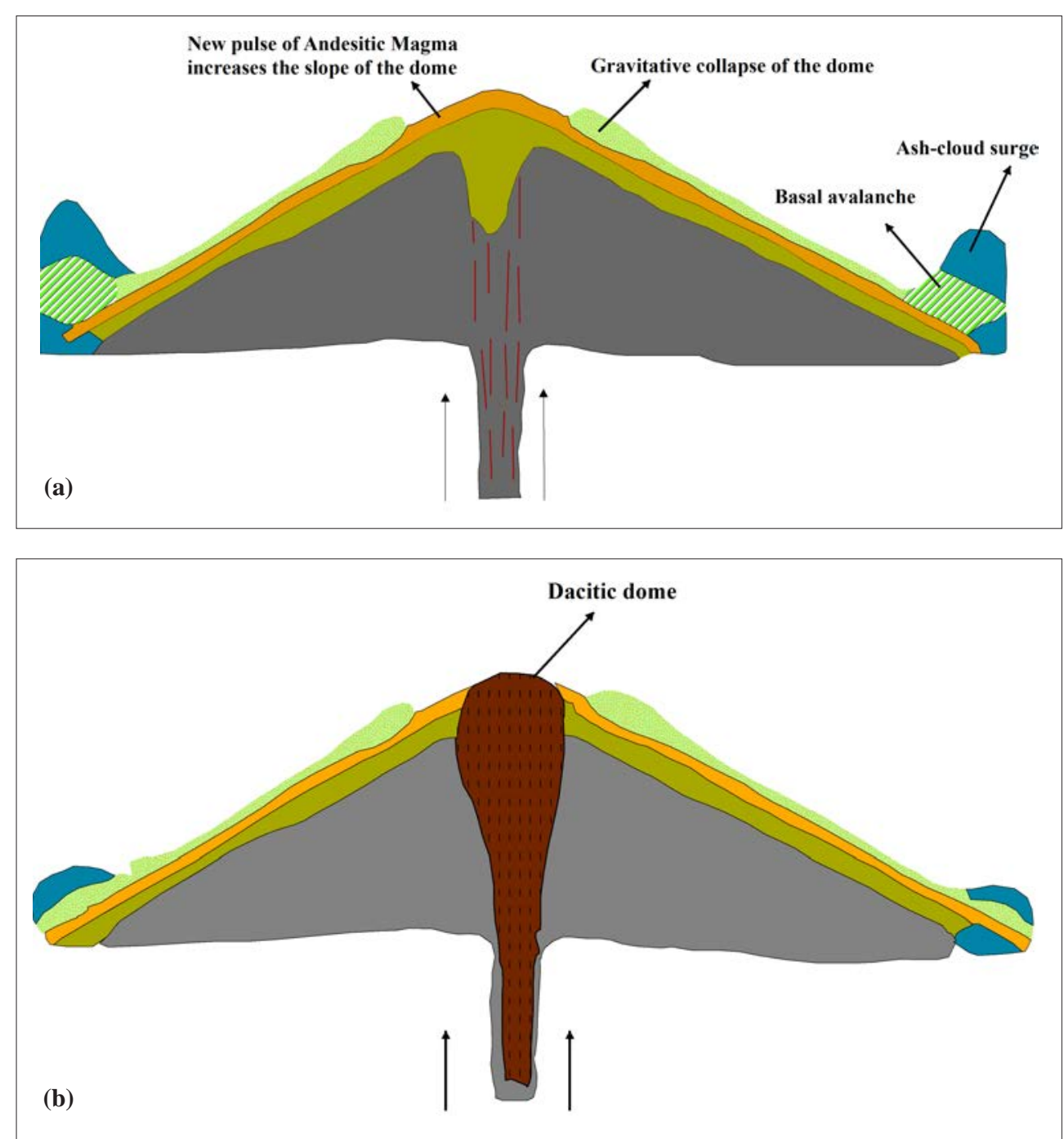

Figure 18 a) Sketch showing evolutionary model of the Narcondam volcano where endogenous growth of andesitic dome later on underwent into gravititative collapse. The hot debris was transported as block-ash flow and during its transport it differentiated into basal avalanche for coarser pyroclasts and ash-cloud surge, b) subsequently the magma changed into highly viscous dacitic composition and dacitic dome extruded the edifice and produced the present day shape of the Narcondam volcano (after Pal and Bhattacharya 2011)

3.5+0.2 Ma (Bhutani et al., 2014). However, dating of the groundmass from the main flows of andesitic lavas has yielded ${ }^{40} \mathrm{Ar} /{ }^{39} \mathrm{Ar}$ plateau ages of c. 0.55-0.56 Ma (Strecks et al., 2011; Bhutani et al., 2014).

\section{Tectonic evolution of the Barren and Narcondam volcanoes}

The Barren and Narcondam volcanoes lie in the same arc line of the Andaman subduction complex but have contrasting chemical composition and different evolutionary history. Geochemistry suggests that both the volcanoes have island arc affinity where Barren volcanics have theoleiitic and Narcondam - volcanics have calc alkaline characters.

A seismic gap in the Andaman Benioff zone at a depth of 90$100 \mathrm{~km}$ has its spatial relation with volcanism on the Barren Island (Dasgupta and Mukhopadhya, 1997). This gap is due to partial melting of the Indian plate and initially hydrous basaltic magma and then a volatile-rich frothy magma underwent into explosive fragmentation from a subaerial open vent (Halder and Luhr, 2003, Pal et al., 2007a, 2010, Bandopadhyay, 2017). A NE-SW trending dyke on the northwestern face of the Barren Island is probably acting as feeder dyke and responsible for the present activity (Chandrashekharan et al., 2009). However, major oxides, trace elements and REE pattern when are considered together the Barren basalt neither show typical island arc nor N-MORB characters. Some of the large ions are enriched compared to island arc tholeiities. Perhaps the subduction zone fluid modified the lava geochemistry of the Barren lava especially for the 1787 onward eruptions.

The Barren volcano occurs almost at the northern tip of $90^{\circ} \mathrm{E}$ ridge. Its position in the intersection of the two tectonic domains puts doubt about its origin either in pure arc or ridge or it has influence of both.

The Narcondam volcano has elevated $\mathrm{Sr}, \mathrm{Ba}, \mathrm{Rb}$ and $\mathrm{U}$ concentrations and high $\mathrm{Ba} / \mathrm{Zr}$ and $\mathrm{Nb} / \mathrm{Zr}$ ratios and significantly more radiogenic isotopic ratios in comparison to Barren lavas. Narcondam lavas were influenced likely by a) crustal contamination during magma residence in the upper plate within extended continental crust and/or b) subduction zone sediments. But strong enrichment in Sr suggests that sediment from subducting plate had a significant role in LILE enrichment in Narcondam volcanics. The crust of the overriding plate underwent partial melting to produce acidic magma and basaltic magma was derived from the subducting plate and overlying mantle.

The dacite-andesite Narcondam magma represents the mixed product of rhyolite and basalt but no end members of lava is reported from the island. Perhaps in the magma conduit of the Narcondam volcano, low density rhyolitic magma trapped the rising basaltic magma but it was not the case in the Barren volcano where the basaltic magma is coming through deep fractures as a focused arc melt.

Based on the current seismotectonic model of the Andaman Sea region Morley et al, 2017 inferred the presence of extended continental crust below the Barren Island but lava characters do not show the influence of continental crust. On the other hand Narcondam magma shows influence of crustal contamination. In that case the continental crust perhaps continued to the extent of the Narcondam Island. 


\section{Acknowledgements}

The author is grateful to the Director General, Geological Survey of India (GSI), Additional Director General of North Eastern Region (NER),GSI for administrative support. The author is thankful to R. Laisram,, Annie Daliya N, and Rohit Gajbhiye of NER,GSI for their support during different stages of the work.

\section{References}

Alam, M.A., Chandrasekharam, D., Vaselli, O., Capaccioni, B., Manetti, P. \& Santo, P.B. 2004. Petrology of the prehistoric lavas and dyke of the Barren Island, Andaman Sea, Indian Ocean. In: Sheth, H.C. \& Pande, K. (eds) Magmatism in India Through Time. Proceedings of the Indian Academy of Science (Earth Planet Science), Indian Academy of Science, Bangalore, 113: 715-721.

Awasthi, N., Ray, J .S. Laskar, A.H., Kumar, A., Sudhakar, M., Bhutani, R., Sheth, H.C., Yadava, M.G., 2010. Major ash eruptions of Barren Island volcano (Andaman Sea) during the past $72 \mathrm{kyr}$ : clues from a sediment core record. Bulletin of Volcanology, 72: 1131-1136.

Bandopadhyay, P. C., 2017. Inner-arc volcanism: Barren and Narcondam islands. In Bandopadhyay, P. C \& carter, A (eds.); The Andaman-Nicobar Accretionary Ridge: Geology, Tectonics and Hazards. The Geological Society of London, Memoir No. 47: 167-192.

Bandopadhyay, P.C., Mitra, S.K., Pal, T., Raghav, S.R., 2006. The 2005 eruption on Barren Island, Andaman Sea. Current Science, 90: 620-622.

Bhattacharya, A., Pal, T. and Bardhan, S., 2012. Physical characterization, petrology and geochemistry of the Barren volcanic Island: An active stratovolcano in Andaman Sea. Geological Survey of India (GSI) report for FS 2009-2011 published in GSI Portal.

Bhutani, R., Pande, K., Ray, J.S., Smitha, R.S., Awasthi, N. \& Kumar, A. 2014. 40Ar-39Ar geochronology of Narcondam island volcano, Andaman- Indonesian island arc, Andaman Sea: voluminous andesitic eruption at $0.56 \mathrm{Ma}$ and preservation of $1.8 \mathrm{Ma}$ old plagioclase xenocrysts. Geological Society of America Abstract, 46: 653.

Chandrasekharam, D., Santo, A.P., Cappuccino, B., Vaselli, O., Manetti, P., Aalam, M.A. \& Tassi, F. 2009. Volcanological and petrological evolution of Barren Island (Andaman Sea, Indian Ocean). Journal of Asian Earth Sciences, 35: 469-487.

Chandrasekharan, D., Vaselli, O., Capaccioni, B., Manetti, P. \& Alam, M.A. 2003. Cold springs of the Barren Island, Andaman Sea, Indian Ocean. Current Science, 85: 136-137.Dasgupta, S. \& Mukhopadhyay, M. 1997. Aseismicity of the Andaman subduction zone and recent volcanism. Journal of Geological Society of India, 49: 513-521.

Evans, P. and Crompton, W., 1946: Geological factors in gravity interpretation illustrated by evidence from India and Burma. Jour. Geol. Soc. London. 102 (3): 211 -249

Haldar, D. \& Luhr, J.F. 2003. The Barren Island volcanism during 1991 and 1994-95: eruptive style and lava petrology. Geological Society of India Memoir, 32: 313-328.

Haldar, D., Banerjee, P.K., Streck, M.J. \& Mukerjee, P. 2007. Quaternary volcanism on the Barren and Narcondam Islands in the Andaman Sea: Arc magmatism within a rift tectonic environment. In: Ray, J. \& Bhattacharya, C. (eds) Igneous Petrology: 21st Centuary Perspective. Allied Publisher Pvt. Limited, New Delhi, 181-234.

Haldar, D., Laskar, T., Bandopadhyay, P.C., Sarkar, N. \& Biswas,
J.K. 1992. Volcanic eruption of the Barren Island volcano, Andaman Sea. Journal of the Geological Society of India, 39: 411-422.

Hobday, J.R. \& Mallet, F.R. 1885. The volcanoes of the Barren Island and Narcondam in the Bay of Bengal; their topography by captain J.R. Hobday, S.C., and Geology by F.R. Mallet. Memoirs of the Geological Survey of India, XXI, Pt 4: 251-286.

Luhr, J.F. and Haldar, D., 2006. Barren Island Volcano (NE Indian Ocean): Island-arc high-alumina basalts produced by troctolite contamination. Journal of Volcanology and Geothermal Research 149: $177-212$.

Mallet, E.R. 1895. Some early illusions to Barren Island: with a few remarks thereon. Records of the Geological Survey of India, 28: 22-34.

Morley, C.K. 2017. Cenozoic rifting, passive margin development and strike-slip faulting in the Andaman Sea: a discussion of established v. new tectonic models. In: Bandopadhyay, P.C. \& Carter, A. (eds) The Andaman-Nicobar Accretionary Ridge: Geology, Tectonics and Hazards. Geological Society, London, Memoirs, 47: 27-50.

Mukhopadhyay, P. K., Pal,T,. Sengupta S., Bhattacharya A. (2009). A report on petrology and geochemistry of volcanic rocks of Narcondam Island, A\& N islands Geological Survey of India (GSI) reports of F.S.-2007-08 published in GSI portal.

Pal, T. \& Bhattacharya, A. 2011. Block-and-ash flow deposit of the Narcondam Volcano: product of dacite-andesite dome collapse in the Burma-Java subduction complex. Island Arcs, 20, 520534.

Pal, T., Bandopadhyay, P.C., Mitra, S.K., Raghav, S.R., 2007a. Recent eruption (2005) of Barren volcano: an explosive inner arc volcanism in Andaman Sea. Journal of the Geological Society of India, 69: 1195-1202.

Pal, T., Mitra, S.K., Sengupta, S., Katari, A., Bandopadhyay, P.C., Bhattacharya, A.K., 2007b. Dacite-andesites of Narcondam volcano in the Andaman Sea - an imprint of magma mixing in the inner arc of the Andaman-Java subduction system. Journal of Volcanology and Geothermal Research 168, 93-113.

Pal, T., Ragav, S., Bhattacharya,A, Bandopadhyay P.C., Sumit K. M., Renjit M.L., Sankar, M.S. and Biswajit Ghosh,B. 2010. The 2005-2006 eruption of the Barren volcano: evolution of basaltic magmatism in island arc setting in Andaman-Java subduction. Journal of Asian Earth Sciences, 43: 112-123.

Ray, J.S., Pande, K. \& Awasthi, N. 2013. A minimum age for the active Barren Island volcano, Andaman Sea. Current Science, 104: 934-939.

Ray, J.S., Pande, K. \& Bhutani, R. 2015. 40Ar/39Ar geochronology of subaerial lava flows of Barren Island volcano and the deep crust beneath the Andaman Island Arc, Burma Microplate. Bulletin of Volcanology, 77: 57.

Shanker, R., Halder, D., Absar, A. \& Chakraborty, S.C., 2001. Pictorial monograph of the Barren Island volcano, the lone active volcano in the Indian subcontinent. Geological Survey of India. Special Publication 67: 87.

Sheth, H. 2014. What drives centuries-long polygenetic scoria cone activity in Barren Island volcano? Journal of Volcanology and Geothermal Research, 289: 64-80.

Sheth, H.C., Ray, J.S., Bhutani, R., Kumar, A. \& Awasthi, N. 2010. The latest (2008-09) eruption of the Barren Island volcano and some thoughts on its hazards, logistics and geotourism. Current Science, 98: 620-627.

Sheth, H.C., Ray, J.S., Bhutani, R., Kumar, A. \& Smitha, R.S. 2009. Volcanology and eruptive styles of Barren Island: an active mafic stratovolcano in the Andaman Sea, NE Indian Ocean. Bulletin of Volcanology, 71: 9-28. 
Sheth, H.C., Ray, J.S., Kumar, A., Bhutani, R. \& Awasthi, N. 2011. Toothpaste lava from the Barren Island volcano (Andaman Sea). Journal of Volcanology and Geothermal Research, 202: 73-82.

Strecks, M.J., Ramos, F., Gillam, A., Haldar, D. \& Duncan, R.A. 2011. The Intra-oceanic Barren Island and Narcondam Arc Volcanoes, Andaman Sea: implications for subduction inputs and crustal overprint of a depleted mantle source. Chapter 11. In: Ray, J., Sen, G. \& Ghosh, B. (eds) Topics in Igneous Petrology. Springer Science, 240-273.

Tamurai, Y., 1994. Genesis of island arc magmas by mantle-derived bimodal magmatism: evidence from the Shirahama Group, Japan. Journal of Petrology, 35: 619-645.

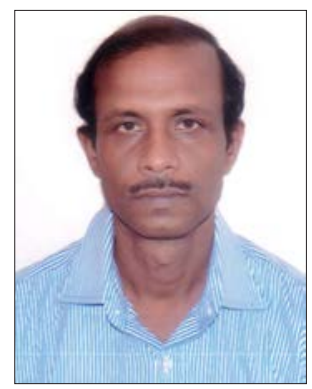

Tapan Pal did PhD on Mineralogy and Petrology of Sukinda ultramafites from the Jadavpur University. He has also post doctoral research experience in UK and Germany. After PhD he has joined Geological Survey of India (GSI) where he has done mapping and research on Precambrian terrain of Meghalaya and convergent plate margin of Andaman Islands including volcanoes. He is a National Mineral Awardee and Fellow of West Bengal Academy of Science and Technology. Now he is involved in the policy support system and giving technical support to all the field programme of North Eastern region of GSI. He has published 22 nos. international papers, 18 nos. national papers and 1 no. book on Andaman Geology. 